\title{
Real Fake? Appropriating Mobility via Schengen Visa in the Context of Biometric Border Controls
}

\author{
Stephan Scheel
}

Department of Sociology, Goldsmiths, University of London, United Kingdom

41 Lewisham Way, New Cross, London, SE14 6NW; e-mail: s.scheel@ gold.ac.uk ; telephone: $0044(0) 2037847091$

\section{Biographical Note}

Stephan Scheel is working as post-doctoral researcher on the ERC-funded project 'ARITHMUS - How Data Make a People' at the sociology department of Goldsmiths, University of London. Before joining the ARITHMUS project, Stephan completed his $\mathrm{PhD}$ at the department of Political and International Studies of the Open University in Milton Keynes (UK). His doctoral thesis has been awarded the Michael Nicholson Prize of the British International Studies Association (BISA) in 2015. It investigates how migrants appropriate mobility in the context of biometric border controls in order to demonstrate the persistence of moments of autonomy of migration in technologically ever more sophisticated border regimes. In general, Stephan's research interests lie at the intersection of border and migration studies, citizenship studies, critical security studies and science and technology studies.

\section{Acknowledgements}

I would like to thank all research participants for their time and for answering my questions, in particular the people who feature as Anas, $\mathrm{M}$ and $\mathrm{P}$ in this article. I would also like to thank Claudia Aradau, Jef Huysmans, Anne McNevin and the two anonymous reviewers who all provided very helpful comments on earlier drafts. This work was supported by funding from the European Research Council under the European Union's Seventh Framework Programme (FP/2007-2013) / ERC Grant Agreement no. 615588. Principal Investigator, Evelyn Ruppert, Goldsmiths, University of London.

\section{Disclosure Statement}

No potential conflict of interest was reported by the author.

\section{Note}

This is the final accepted, pre-typeset version of article which has been published in the Journal of Ethnic and Migration Studies. For further info and original version follow this link:

https://doi.org/10.1080/1369183X.2017.1401513 


\title{
Real Fake? Appropriating Mobility via Schengen Visa in the Context of Biometric Border Controls
}

\begin{abstract}
Although the majority of illegalised migrants in the European Union are so-called 'visa overstayers' who enter with a Schengen visa only to become 'illegal' once it has expired, this mode of illegalised migration has only received scarce attention in border and migration studies so far. This article takes the introduction of biometric technologies in the Schengen visa regime as an opportunity to compensate for this neglect by asking: How do migrants appropriate Schengen visa in the context of biometric border controls? Drawing on the autonomy of migration approach (AoM), it investigates the visa regime from the perspective of mobility in order to elaborate on one set of practices of appropriation that involves the provision of falsified or manipulated supporting documents upon which the decision to issue a biometric visa is based. The article draws on this example to develop a conception of the notion of appropriation that addresses the two central criticisms that have been raised against the AoM. Besides contributing to the development of the AoM, the article thus introduces a concept in debates on migrant agency that highlights, better than existing concepts, the intricate intertwinement of migrants' practices with the actors, means and methods of mobility control.
\end{abstract}

Keywords: Autonomy of migration, biometric borders, irregular migration, migrant agency, visa policy

\section{Introduction}

To date the Schengen visa regime has been relatively neglected in border and migration studies, especially when compared with the attention that more visible forms of border control and irregular migration have received. The amount of literature on migration control agencies like FRONTEX or the IOM, detention centres, deportations or the fortification of borders through fences sits in stark to the manageable body of literature on the Schengen visa regime. So far the latter has been criticised as a means for governing mobility 'at a distance' (Bigo and Guild 2005), as being incommensurable with liberal principles (Brabandt and Mau 2013) and for creating highly unequal access to mobility (Hobolth 2012; Mau 2010; Neumayer 2006; Van Houtum 2010). Furthermore, ethnographic studies have revealed the official representation of the visa application procedure as a rational, transparent bureaucratic process as a myth (Alpes 
2011; Alpes and Spire 2014; Infantino and Rea 2012; Spire 2009; Zampagni 2016). Yet, to date we know very little about how migrants transform this regime of mobility control into a migration channel. This neglect is astonishing as there is strong evidence that the majority of illegalised migrants arrive perfectly legal with a valid Schengen visa in the European Union (EU) and only become 'illegal' once it has expired (Düvell 2011; Zampagni 2013; Jansen, Celikates, and De Bloois 2015). ${ }^{1}$ From this perspective the consulates of Schengen member states constitute what the editors of this special issue call 'spaces of asymmetrical negotiation' - sites in which border controls are implemented and contested (Eule, Loher, and Wyss 2017).

This article takes the introduction of biometric technologies as new measures of control in Schengen visa issuing consulates as an opportunity to compensate for the neglect of this important mode of illegalised migration in the existing literature. In October 2011 the Visa Information System (VIS) started to operate in all consulates of Schengen member states in six countries in North Africa. ${ }^{2}$ In addition, the European Commission (EC) is planning a biometric Entry-Exit System that is supposed to assist authorities in the detection of (visa) overstayers (see: Sontowski 2017, in this issue). This article will however focus on the VIS which is meant to prevent some of the practices that migrants have mobilised so far to appropriate Schengen visa as a way to enter Europe. ${ }^{3}$ The VIS stores the fingerprints and facial images of the up to 12 million people who annually apply for a Schengen visa for a period of five years (Broeders 2007). By rendering visa applicants' bodies as means of re-identification the VIS is meant to forestall practices like the lodging of multiple applications by the same person at several Schengen visa issuing consulates (so-called 'visa shopping') or the usage of passports with valid Schengen visa by so-called lookalikes. Thus, the introduction of the VIS raises the question how migrants appropriate mobility to Europe via Schengen visa in the context of biometric border controls.

This question indicates that I investigate the Schengen visa regime from the perspective of those whose mobility is assessed and restricted by this now biometrified control regime. The autonomy of migration approach (AoM) provides the theoretical foundation for adopting the perspective of mobility. What distinguishes the AoM from other approaches in border and migration studies is precisely that it makes migrants' practices the starting point of the analysis of border regimes and migratory processes (Moulier Boutang 2007; Mezzadra 2011). As indicated by its name, the core thesis of the AoM claims that migrations yield moments of autonomy, that is moments of uncontrollability and excess, in regards to any attempt to control or regulate them (Moulier Boutang 1993). This attribution of moments of autonomy permits 
migration to be apprehended as a constituent force that forces border regimes in processes of adaptation and reorganisation (Papadopoulos, Stephenson, and Tsianos 2008).

Yet, the AoM is controversial. Both the autonomy of migration thesis and the reading of migration as a constituent force have been accused of romanticizing migration. This major critique is driven by two objections: On the one hand, critics maintain the AoM would not sufficiently account for the highly varying conditions under which people migrate (Benz and Schwenken 2005; Sharma 2009). On the other hand, the AoM is accused of downplaying the restrictive effects of ever more pervasive border controls (Omwenyeke 2004). What is needed in order to address these two criticisms is a concept that mediates between the assertion of an abstract autonomy of migration and the subjective practices of embodied migrants who are inscribed in particular constellations of power relations in terms of class, 'race' and gender and who are struggling against particular modes of border control (Scheel 2013a, 2013b). Besides answering the rather empirical question of how migrants appropriate mobility to Europe via Schengen visas in the context of biometric border controls, the second objective of this article is therefore to develop the notion of appropriation as a concept that addresses the two criticisms outlined above. Thus, the article contributes to debates on migrant agency by introducing the notion of appropriation as a concept that highlights, in particular, the intricate intertwinement of migrants' practices with the means and methods of control.

The article is subdivided in two sections. The first part explains why the Schengen visa regime constitutes, from the perspective of visa applicants, an unpredictable regime of institutionalised distrust that entices the former to engage in various practices of appropriation to increase the chances of success of their visa application. Subsequently, I discuss the implications of the VIS by reading it as an attempt to recuperate previously successful practices of appropriation. The second part elaborates on one set of practices of appropriation that is still possible in context of the VIS. It involves the provision of manipulated or falsified supporting documents upon which the decision to issue a visa is based. I use this example to tease out six features that practices of appropriation share irrespective of their form.

The following account of the Schengen visa regime, the introduction of the VIS and migrants' practices of appropriation is based on extensive ethnographic fieldwork that I have conducted in a North African country in 2012. During two field visits of three weeks I observed all phases of the visa application and decision-making procedures in a Schengen visa issuing consulate. In the following I refer to this consulate only as consulate $\mathrm{Z}$ for reasons of anonymisation. These participant observations have been complemented by more than 40 interviews with visa applicants, consular staff and members of staff of other consulates. 


\section{The Schengen visa regime: provoking and recuperating practices of appropriation}

This section provides the context in which migrants try to appropriate mobility to Europe via Schengen visa. To this end, I will briefly explain why the Schengen visa resembles, from the perspective of the billions of people who are subjected to a visa requirement, an unpredictable regime of institutionalised distrust that provokes them to engage in various practices of appropriation in order to gain an 'entry-ticket' to Europe. ${ }^{4}$ The principal reason for this dynamic is that the Schengen visa regime renders mobility to Europe a scarce resource through the introduction of an entry-ticket, namely a Schengen visa. The receipt of such an 'entryticket' is however subject to the passing of a pre-screening process - the visa application procedure. According to Article 21 of the Community Code on Visas (CCV), the legal basis for the Schengen visa regime, the principal objective of the visa application procedure is to 'assess[...] whether the applicant presents a risk of illegal immigration or a risk to the security of the Member States and whether the applicant intends to leave the territory of the Member States before the expiry of the visa applied for' (EP and Council 2009b, 12; my emphasis). In practice, a visa applicant has to prove in an interview and through the provision of numerous documents that she does not constitute a security or 'migration risk'. This brief account permits to unearth three features of the operational logic of the visa application procedure that explain why the Schengen visa regime constitutes an unpredictable regime of institutionalised distrust that provokes the very practices it is meant to forestall: various practices of appropriation.

What the passage from the CCV cited above illustrates is, first, that visa applicants enter the consulates of Schengen member states as suspects. Through the imposition of a visa requirement the entire population of a particular country is subjected to the general suspicion of constituting a 'risk' in terms of migration or security. ${ }^{5}$ It is thus the assessment of a population in terms of risks which allows to subject those wishing to travel to Europe to indepth control in their country of departure and before they have started to move. This dislocation of border controls in both space and time constitutes the raison d'être of the Schengen visa regime (Bigo and Guild 2005). For visa applicants, their subjection to a general suspicion implies however that the assumption of innocence is reversed in the application procedure: consular staff always start from the negative and it is the applicant who has to convince consular staff that she does not intend to migrate. Hence, the risk assessment, which underpins both the imposition of a visa requirement and the application procedure, institutes a 'suspicion by default' approach in the consulates (Zampagni 2013, 96). Thereby the Schengen visa regime's risk management approach generates high degrees of uncertainty for visa applicants, who have 
to lodge their application in a climate of institutionalised distrust and who do not know the criteria against which they will be judged, as I explain below.

To convince consular staff that they do not constitute a migration or security risk (contrary to the general suspicion justifying the visa requirement in the first place), visa applicants have to provide numerous documents, whose exact quantity and quality depends on the type of visa they apply for, but also varies from one visa section to the next. The crucial point is that these formal requirements for a visa often do not correspond to local circumstances. The consulate in which I could observe the visa application and decision making procedure (in the following consulate $\mathrm{Z}$ ), requires, for instance, no less than ten different types of documents for a tourist visa, including bank statements, proof of means of subsistence ( 88 euros per person per day), an employment contract, salary slips for the past three months, a social security card and a print-out of social security contributions for the past 12 months. Yet, the provision of some of these documents may prove impossible for many people, as they do not reflect the working and living conditions of a large share of the local population, not only in the country I visited but also in many other countries subject to a visa requirement. In the context of a large informal economy, many people do, for instance, not have a bank account. Nor do they pay social security contributions (Alpes 2011, 116-117). That the paper requirements for a Schengen visa are often removed from local realities was also admitted in an interview by an employee of an embassy which harbours one of the largest visa sections in the country I visited. In the context of a large informal economy, the employee reported, even very rich business people may find it difficult to provide documents confirming their wealth. The same would apply to farmers who cannot provide evidence of the land they own due to incomplete registers.

But even if people can fulfil the formal requirements for applying for a visa they may fall short of fulfilling the informal requirements for a Schengen visa. The head of the visa section at consulate $Z$, for instance, considers any application for a tourist visa dubious, because the member state he represents 'is certainly not the most attractive tourist destination in Europe.' Hence, he only issues tourist visas to people who have previously visited Europe and have a permanent job with a significant income. Likewise, the head of a visa section that does represent an attractive tourist destination boasts in an interview: 'Anybody who does not earn at least double the average monthly income will not get a visa from me.' It goes without saying that this requirement cannot be fulfilled by the large majority of the population.

By efficiently barring a large share of the local population from even applying for visa through a wall of documents they cannot provide and a set of informal requirements they cannot fulfil the visa regime provokes various practices of appropriation as the falsification of 
supporting documents like bank statements or social security records. From the perspective of visa applicants such practices constitute a form of 'forced fraud' (Garcia 1997) which is enticed by highly restrictive requirements for a Schengen visa that do not correspond to local realities.

The third reason why the Schengen visa regime provokes the very practices it is meant to forestall is that it is unpredictable for visa applicants, not only in regards to its procedures but also, and most importantly, in regards to its outcomes. There are several reasons for this unpredictability, starting with the heterogeneity of consular practices which vary considerably from one consulate to the next (cf. Infantino 2016). This heterogeneity plays itself out most brutally for visa applicants in the form of a highly variable decision-making praxis. In 2011 the refusal rate across consulates receiving more than 1,000 applications per year varied between $6 \%$ and over $35 \%$ in the country I visited according to official statistics. 'Each country applies its own policy', summarises the head of consulate Z's visa section (hereafter: M) the situation. However, what makes the decision-making unpredictable for visa applicants is not only the heterogeneity of practices across consular, but also the discretionary power of consular staff in conjunction with the visa regime's risk management approach, which introduces an irreducible moment of interpretation in the decision-making procedure, as I explain now.

Whenever I asked consular staff how they decide on visa applications I received the same answer as Alexis Spire $(2009,80)$ in his study on French migration administrations: 'on a case by case basis'. M defended this case-by-case approach as 'sensible', arguing that it would grant consular staff the 'flexibility that is necessary to assess each case individually.' This justification of consular staff's 'flexibility' in the decision-making confirms that discretion constitutes an irreducible 'part of the reality of policy implementation' as it permits street-level-bureaucrats working on the frontline to adapt abstract laws and regulations to individual cases and local circumstances (Bouchard and Carroll 2002, 242; Lipsky 1980, 16). Consular staff often emphasised that the definition of any clear-cut decision criteria would prove to be impossible. Since 'each dossier is different', as they put it, consular staff have to interpret each individual dossier in order to adapt it to the general provisions of abstract laws and regulations. It is thus the task to 'assess' the 'migration risk' of a visa applicant, the practical implementation of article 21 cited above (EP and Council 2009b, 12), that introduces an irreducible moment of interpretation in the decision-making. And it is this irreducible moment of interpretation - which is inherent to any assessment of risk - that makes the decision-making procedure unpredictable for visa applicants because it results in decision criteria that vary from one consulate to the next. 
Nevertheless, consular staff's decision-making is unpredictable, but nor arbitrary as which it often described by NGOs and visa applicants (e.g. CIMADE 2010). The reason is that consular staff's decision-making is shaped by local practical knowledge, which imbues their decisions with relative coherency, as Federica Infantino and Andrea Rea (2012) have shown. This finding is confirmed by my own research which suggests that the task of 'assessing' the 'migration risk' posed by a visa applicant compels consular staff to make decisions under conditions of time-constraint, incomplete information and uncertainty. Since consular staff have no direct access to applicants' intentions, their 'assessment' of an applicant's 'migration risk' is based primarily on interpretation. But this interpretation does not occur in a void. It is shaped by practical knowledge and informal decision-making criteria that circulate among consular staff in the form of stories about legendary cases which function as reference points for consular staff's decisions, as illustrated by the following example.

'This applicant shows the profile of a young person from a deprived area in the South who seeks to establish relationships with tourists, enabling him to apply for a visa to Europe. A possible marriage cannot be ruled out.' This is one of the many entries by counter staff at consulate $\mathrm{Z}$ that features the notions of 'risk' and 'profile'. It illustrates that consular staff interpret a particular combination of certain biographical features as indicators of the presence or absence of 'migration risk'. But this example equally shows that these interpretations are shaped by local practical knowledge that surfaces in the form of prototype cases. Consular staff 'assess' the 'migration risk' of an applicant by looking for patterns in the biographical features and narratives of visa applicants in order to compare them with and allocate them to one of the 'profiles' of these prototype cases. Hence, consular staff's decisions are not arbitrary because they are bestowed with a relative coherency by informal decision-making criteria that circulate among consular staff in the form of advice and stories about certain legendary cases that are subsequently codified as informal 'profiles' and 'types' of applicants. In conjunction with a culture of institutionalised distrust and a shared ethos among consular staff, who tend to regard themselves as protectors of national identity and 'defenders of the welfare state' (Infantino and Rea 2012, 74; Spire 2009, 58-60), it is this local practical knowledge that imbues consular staff's decision-making with a relative coherency. The finding that decision-making practices by street-level bureaucrats in the consulates are not arbitrary as they are guided and shaped by informally institutionalised decision-making frameworks confirms studies on decision-making on the street-level in other institutions (see for instance: Hawkins 1992; Maynard-Moony and Musheno 2003; Gofen 2013). 
While this relative coherency explains, why consular staff's decisions are not arbitrary, their decisions remain, nevertheless, largely unpredictable for applicants for the following three reasons. First, there remains a variance within the relative coherence of the decision-making praxis in each visa section due to the discretionary power of consular staff (Spire 2009, 61-79). Second, the informal criteria and prototype cases that inform consular staff's decisions are not known to visa applicants. The latter can only vaguely infer these from successful applications of other applicants, as I explain in the next section. Finally, decisions on visa applications remain unpredictable because my research suggests that the practical knowledge that bestows consular staff's decision-making praxis with a certain coherency within one visa section varies from one consulate to the next (cf. Scheel forthcoming).

It is however important to note that the uncertainty created by the unpredictability of the decision-making procedure 'is not equal for everyone' (Alpes 2011, 120). Members of the local elites can be relatively certain of getting a visa because their 'profile' corresponds to that of a bona fide traveller. A second group of people, including the unemployed and those working in the informal sector, can in turn be certain that they will not be granted a visa as long as they play by the rules. But for a significant share of people the result of their visa application is highly uncertain as they are confronted with a bureaucratic process that is unpredictable in regards to its outcomes due to the irreducible moment of interpretation involved in consular staff's decision-making and the opacity and variability of the criteria they deploy to 'assess' the alleged 'migration risk' of an applicant.

Besides the institutionalisation of a culture of distrust in the consulates and the setting of requirements for a visa that do not correspond to the living conditions of a large share of the local population, it is the opacity and variability of the informal criteria used by consular staff in their decision-making that prompt people willing to move to engage in various practices of appropriation in the hope of increasing the prospects of success for their visa application. Practices like applying at a consulate that has a reputation for being less 'strict' than the representation of the member state that constitutes an applicant's travel destination, or concealing biographical features that may be interpreted as indicators of a 'migration risk' by consular staff, such as family ties in Europe, are prosecuted as 'visa shopping' and instances of 'fraud'. ${ }^{6}$ From the viewpoint of visa applicants these and other practices of appropriation constitute, however, tactics that are needed to negotiate the uncertainty that the unpredictable decision-making procedure generates for them and in order to appropriate a visa within and against a strict bureaucratic regime that sets requirements for a visa that are impossible to fulfil unless one engages in various kinds of 'forced fraud' (Garcia 1997). 
Yet, the introduction of the biometric database VIS, which is meant to serve the EU as a multipurpose tool in its self-proclaimed 'fight against illegal immigration' forestalls some of the practices by which aspiring migrants could previously successfully appropriate mobility to Europe via Schengen visa. To this end, the fingerprints and facial images of all visa applicants are captured in the consulates during the visa application procedure. This biometric data is the stored, together with comprehensive biographical information, in digitised form in the VIS for a period of five years. During border checks this data can be retrieved from the database and be used to either verify the claimed identity of a person or to establish the identity of a person with a record in the biometric database. In this way the VIS functions as a 'system of reidentification' (Broeders 2011, 85-86) that efficiently turns migrants' bodies into means of mobility control (Scheel 2013a, 595).

As a result of this technological innovation it is, for example, no longer possible to use stolen blank visa stickers, or to hand on passports with valid Schengen visa to so-called 'lookalikes'. If no corresponding file exists in the VIS it is very likely that the person concerned will be denied entry upon arrival at the external borders of Europe. Since the introduction of the VIS it has become mandatory for border guards to capture the fingerprints of all visa holders and compare them with data held in the VIS (EP and Council 2009a). The aim of this so-called verification procedure is to confirm that the person is the same to whom the presented visa has been issued. The VIS also makes it easier for consular staff to detect the lodging of several visa applications at different consulates by the same person. Consular staff can now forestall this form of visa shopping because they can now check in the VIS, 'if this fingerprint has already applied for a visa', as a senior border guard put it in an interview. ${ }^{7}$ What these examples illustrate is that the introduction of the VIS raises a crucial question, namely: How can migrants appropriate mobility to Europe via Schengen visa in the context of biometric border controls?

\section{Practices of appropriation: Repurposing the means and methods of mobility control}

During my fieldwork I have encountered various ways of appropriating mobility to Europe via Schengen visas (cf. Scheel forthcoming). Due to space constraints I can only elaborate on one mode of appropriation here. It involves the provision of manipulated or falsified supporting documents on which the decision to issue a Schengen visa is based. Since the VIS does not contribute to the verification of supporting documents this mode of appropriation is likely to become more important in the context of biometric border controls, as the first VIS evaluation report acknowledges (EC 2016, 31). In the following I will use this example to outline six 
features that practices of appropriation share irrespective of their form. The aim is to develop a conception of the notion of appropriation that mediates between the assertion of an abstract autonomy of migration and the concrete practices of embodied migrant subjects in order to address the two major criticism against the AoM approach.

During my second visit to consulate Z, I hear two members of staff working in the backoffice discussing how they should proceed with an applicant who has presented a manipulated press card when he applied for short-term business visa as a journalist. The two members of staff of consulate $\mathrm{Z}$ debate whether they should call the police or only add the applicant's name to the so-called 'blacklist' of consulate Z. ${ }^{8}$ Eventually, they decide against notifying the local authorities, concluding their discussion with the words: 'It's either going to be the blacklist or nothing!' When I ask P, whom I have observed all morning whilst he received visa applicants at the counter, in the coffee-break about the wannabe journalist, P explains that the man's attempt was detected because the press card had shown signs of manipulation: scratch marks indicated that someone had changed the name of the press card holder. When I ask how often $\mathrm{P}$ and his colleagues detect similar attempts to obtain Schengen visa through the provision of falsified or manipulated feeder documents, P replies vaguely that this would vary from month to month: 'Sometimes we detect several attempts per day, sometimes we have a week without any attempt. It really depends on the season and how many application we receive. In summer we do not have enough time to check. We do not control this enough.' While P's answer points to a shortage of resources as a major limitation to consular staff's capacity to forestall this form of appropriation, many visa sections are actually investing considerable effort in the control of supporting documents. All visa sections I have visited - including that of consulate $\mathrm{Z}$ - deploy a varying arsenal of constantly refined control mechanisms. There exists, however, another major limitation to consular staff's capacity to control the authenticity of supporting documents which consists of a type of manipulated documents that are nearly impossible to detect, as will explain in detail below.

Since not every attempt is detected it is difficult to quantify the attempts to appropriate Schengen visa through the provision of falsified or manipulated supporting documents. A government report on French consulates describes the phenomenon as 'endemic', before citing figures provided by the French minister of foreign affairs, who claims that between 30 and $80 \%$ of all supporting documents that were checked by officials were found to be 'fraudulent' in some countries in Africa (Gouteyron 2007, 49). While these alarming figures have to be treated with care, my research suggests that providing falsified or manipulated supporting documents 
like job contracts, salary slips or bank statements constitutes, indeed, one of the preferred methods to appropriate Schengen visa.

What the example of the manipulated press card illustrates is the contested status of the supporting documents, which function as stakes in migrants' struggles over access to mobility. For consular staff like P, press cards and other supporting documents constitute a device of control for the verification of the socioeconomic situation of applicants and their hosts. Article 21 of the CCV stipulates: "The examination of an application shall be based notably on the authenticity and reliability of the documents submitted and on the veracity and reliability of the statements made by the applicant' (EP and Council 2009b, 12). The example of the manipulated press card shows, in turn, that applicants primarily regard the requested supporting documents as obstacles to be negotiated in order to receive an entry ticket to the Schengen area. From their perspective, the falsification and manipulation of supporting documents constitutes an attempt to repurpose these devices of control into means for appropriating mobility.

Hence, the first feature of practices of appropriation is that they operate through the recoding of the actors, means and methods of mobility control into means of its appropriation. This capacity of migrants stems from the logic of contemporary border regimes to make people willing to move and when on the move complicit in the control of their mobility. Migrants are implicated in the control of their mobility not only as passive objects, but also as acting subjects, because the capacity of border regimes to regulate human mobility derives from, but also hinges on, the active participation of those whose mobility they are designed to govern. Supporting documents like bank statements or social security records are requested by the consulate, but they are provided by the visa applicant. It is this active involvement of people in the government of their mobility which implies that travellers and migrants can articulate their capacity to act in ways which convert the actors, means and methods of control into mechanisms allowing for the appropriation of mobility.

This observation indicates, secondly, that practices of appropriation are inseparably intertwined with the actors, means, methods, operational logics and effects of mobility control. What aspiring migrants and travellers try to achieve through the provision of falsified or manipulated supporting documents is to transform the functional overdetermination of the Schengen visa regime into a pathway to mobility. This functional overdetermination resides in in its multiple 'objectives of promoting exchanges among civil society, of meeting the demand for skilled labour, of attracting investment and business without enhancing the risk of irregular migration' (Parusel and Schneider 2012, 45). 
While applicants do not know the criteria that guide consular staff's decision-making they do nevertheless have a sense of these criteria. How and where to get a visa is a topic of intense debate in the country I visited, precisely because people are confronted with an unpredictable regime of institutionalised distrust. Hence, a superficial knowledge of consular staff's informal decision-making criteria circulates in the form of rumours and stories about people whose applications have either been refused or accepted by a particular consulate. Due to these rumours, aspiring migrants sense that they have to provide evidence that they have 'something to lose', 'something to return to' in their country of origin if they want to convince consular staff of their 'will to return'. Thus, many applicants resort to falsifying supporting documents. Or they manipulate their content in such a way that the fictitious biographies these documents support correspond to the perceived 'profile' of a bona fide traveller. As Anas, the teacher whom I met outside a large visa-section put it: 'The secret is to look good on paper.'

The reason for this intricate entanglement of practices of control and subversion in the context of migration are the highly asymmetrical power relations at sites of border control. At consulates, visa applicants must behave within the narrow parameters set by this site of control: they must provide all the requested documents, answer all questions asked by consular staff and - since VIS began operation - have their fingerprints taken. A refusal to comply with any of these regulations results in the automatic refusal of a visa. It is these highly asymmetrical power relations that explain why, rather than openly contesting restrictive border regimes, migrants usually try recode the mechanisms of control into means of appropriation. And it is these highly asymmetrical power relations that compel migrants to execute this repurposing secretly and unnoticed if their attempts are to be successful. Practices of appropriation, then, constitute both an 'art' (de Certeau 1984, 37) and a 'weapon of the weak' (Scott 1985). Since practices of appropriation operate - like the tactics described by Michel de Certeau $(1984,37)$ - in an environment they do not own, remaining undetected, and this is their third shared feature, is a precondition of success for practices of appropriation. ${ }^{9}$

For consular staff are, as indicated by the example of the press card cited above, of course aware of attempts to appropriate visas through the provision of falsified or manipulated supporting documents. Applicants who provide self-fabricated documents run the highest risk of being detected. Consular staff reported documents containing clumsily scanned stamps or apparently altered names. This shows that appropriating Schengen visa by staging a fictitious biography backed-up by manipulated or falsified feeder documents demands skills, knowledge and social contacts which not all people possess. 
These failed attempts also highlight that the recoding of the actors, mechanisms and methods of control into means of appropriation involves the clandestine transgression of the norms, official regulations and informal rules of contemporary border regimes. Through the clandestine transgression of the parameters of legitimate behaviour laid out for them, and this is the fourth feature of practices of appropriation, migrants initiate a relation of irreconcilable conflict between migration and the attempts to regulate it. This relation of conflict manifests in dialogues of action between migrants who try to appropriate a visa by providing manipulated documents and consular staff trying to detect these attempts. It is through the study of migrants' embodied encounters with the actors, means and methods of mobility control that these conflictive dialogues of action can be investigated (Scheel 2013b).

In these conflictive dialogues of action migrants confront ever more sophisticated means and methods of surveillance and control that can, in fact, be read as recuperated forms of previously successful practices of appropriation, as I show elsewhere (Scheel forthcoming). One head of a middle-sized visa section cites, for instance, the employment of local staff, who can tell if the appearance, statements and behaviour of an applicant correspond to her claimed socioeconomic standing, as an important safeguard against the use of manipulated supporting documents. This indicates the importance of impression management in the interview situation. If applicants claim to hold a higher socioeconomic position than they actually have, they need to dress up and prepare for possible questions in regards to their claimed profession. A salesman in a shabby business suit who purports to do business in Europe without speaking a single word of French or English or knowing the price of the goods he purports to purchase will not be believed. Migrants who try to appropriate a visa by providing manipulated or falsified supporting documents have to maintain a strict 'dramaturgical discipline' with the script of the fictitious biography their documents are meant to support: They should 'not commit unmeant gestures or faux pas in performing it' and should be able cope with 'dramaturgical contingencies as they arise', such as an unexpected question from consular staff (Goffman 1959, 216).

Any incoherency between applicants' fictitious biographies and their appearance, statements and behaviour in the interview may prompt consular staff to engage in additional background checks. In case of doubt, consular staff may call banks, universities and employers to verify the information provided by employment contracts, certificates and bank statements (Spire 2009, 93). Staff at consulate Z verify the applicant's social security records to check the information given on bank statements, employment contracts and payslips. Each day M sends a list of social security numbers from cases that have raised his suspicions to the local 
administration to verify that the information on the social security records provided is correct and corresponds to an applicant's claimed income. Some member states also send specially trained border guards who use UV lamps, magnifying cameras and forgery detectors to check passports and supporting documents for traces of manipulation and falsification. If they detect manipulated or falsified supporting documents, a visa application will automatically be refused. In addition, consular staff may add, as in the example of the detected wannabe journalist, the applicant's name to the visa section's 'blacklist'.

Yet, despite the introduction of ever more sophisticated methods of control and ever more pervasive security technologies like the VIS there exists one form of manipulated feeder documents that are, in the words of consular staff, 'nearly impossible to detect'. In the country I visited they are known as 'vrais faux' which one can roughly translate with 'real fakes'. Since 'the secret is to look good on paper', people may ask a friend or relative who owns a company to 'hire' them in order to obtain the employment contract and payslips required for a successful visa application, Anas tells me over coffee. 'What you need is a skilled job, like an engineer, a teacher or a receptionist in a large hotel', before adding: 'many people do that'. The existence of this practice is confirmed by an employee of the embassy with one of the largest visa sections in the country I have visited. When I ask her about the authentication of supporting documents she replies: 'Many people ask a friend or relative to provide them with an employment contract. These 'real fakes' are nearly impossible to detect because they are essentially originals [...].'10

Even if consular staff call the company that has issued the documents they will not discover that the applicant is only employed on paper since the person answering the phone will confirm all the information in the documents. Similarly, a request at the social security office will not reveal the employment as fictitious, because the friend who 'employs' the person who requires an employment contract is required by law to pay social security contributions for her 'employee'. In practice, the latter would reimburse her 'employer' for the monthly contributions. Hence, the social security records provided by a fictitiously employed applicant are just as 'real' as her employment contract and her payslips: all these documents are originals, issued by actually existing companies and administrations, but the employment relation they support is fictitious.

What the appropriation of Schengen visa through 'real fakes' demonstrates is that identity remains a 'battleground' (Groebner 2004, 182) despite attempts to render migrants' bodies a means of mobility control through the introduction of biometric databases. The VIS does not contribute to the verification of the authenticity of the supporting documents upon which the decision to issue a biometric Schengen visa is based (Muller 2010, 19). Ultimately, 
the appropriation of Schengen visas through 'real fakes' confirms that biometric recognition systems are haunted by the very problem they are meant to solve, because 'any foreseeable system will be based on exactly the document-based methods of identification upon which biometrics are supposed to be an improvement' (Gold 2012, 11).

The fact that this play with identities is still possible in the context of biometric border controls illustrates that moments of uncontrollability of migratory practices, that is moments of autonomy of migration, emerge ironically when migrants stage a convincing performance of compliance with the Schengen visa regime's formal and informal requirements. The provision of manipulated documents that are nearly impossible to detect has to be complemented by a credible imitation of the dress codes, behaviours and biographical features of the bona fide travellers aspiring migrants purport to be. It is, paradoxically, in these performances of compliance that the political quality of practices of appropriation comes to the fore: by staging a performance of feigned compliance with formal rules and informal criteria, migrants take what these rules and criteria are meant to deprive them of: access to mobility. The crucial point is that migrants self-authorise themselves to take the resources border regimes seek to deprive them of without and instead of claiming them from someone. It is this moment of self-authorisation, in conjunction with the clandestine transgression of the informal rules and official regulations of border regimes, which bestows practices of appropriation, and this is their fifth feature, with an irreducible political quality.

Though migrants try to avoid attracting any attention when they try to appropriate mobility via Schengen visa, they nevertheless render border controls, and the legally codified forms of citizenship and the socio-economic status quo border controls are meant to establish and maintain, as objects of contestation and dissent. Instead of openly opposing restrictive migration regulations and related mechanisms of control, practices of appropriation challenge border controls and the status quo they try to secure by staging credible performances of the scripts of mobile subjectivities like middle-class tourists or business people, whose 'profiles' are regarded as devoid of any 'migration risk'. Thereby, migrants erode the informal criteria that guide the decisions of consular staff, ultimately, plunging the Schengen visa regime in an epistemic crisis. Since 'real fakes' are nearly impossible to detect, consular staff can no longer tell whether they are dealing with a 'real' or a 'fake' tourist, student or businessman, because the supporting documents provided may not only be 'fake', 'real', or 'fakingly real', but they could also be 'real fakes'.

Yet, the appropriation of a Schengen visa through the provision of 'real fakes' and the successful imitation of the appearance of a bona fide traveller does not signify an unequivocal 
'victory' of migrants over biometric border control technologies. Rather, it underscores the irreducible ambivalence of practices of appropriation as their sixth and final feature. What makes practices of appropriation ambivalent is their intertwinement with the means and methods of mobility control. The re-coding of the devices, actors, operational logics and effects of mobility control in means of appropriation implies concessions, compromises and sideeffects which may prove to be detrimental for migrants and their migration projects in the long run. Migrants cannot completely usurp the means and methods of control for their own purposes. This is why practices of appropriation usually result in contested, and polyvalent outcomes that imply further struggles over the appropriation of mobility, whereby each of these struggles features its own set of sites, actors and stakes. It is thus the irreducible ambivalence of migrants' practices of appropriation that inserts a self-perpetuating dynamic into migrants' struggles over mobility to Europe. The final paragraph of the visa application form, above the field reserved for the applicant's signature, is indicative of this self-perpetuating dynamic:

I undertake to leave the territory of the Member States before the expiry of the visa, if granted. I have been informed that possession of a visa is only one of the prerequisites for entry into the European territory of the Member States. The mere fact that a visa has been granted to me does not mean that I will be entitled to compensation if I fail to comply with the relevant provisions of Article 5(1) of Regulation (EC) No 562/2006 (Schengen Borders Code) and I am therefore refused entry. The prerequisites for entry will be checked again on entry into the European territory of the Member States (as cited in: EP and Council 2009b, 29).

What the statement that a visa does not guarantee entry to the Schengen area indicates is that the successful appropriation of a Schengen visa leads to another struggle over the selective denial and direct appropriation of mobility. This struggle takes places upon arrival at the external border of the Schengen area and revolves around the conditions of entry. The first line of the paragraph indicates, in contrast, that migrants will face further struggles over mobility and other resources after a successful border crossing. The appropriation of mobility via Schengen visa results in a compromise as it also implies migrants' disenfranchisement by the border regime: living and working in Europe is now possible, but only under the precarious and contested conditions of illegality (Karakayali and Tsianos 2005). After the expiration of their visas migrants become 'illegal', rendering the entire Schengen area a vast borderzone crisscrossed by struggles revolving around the appropriation of various resources such as an income, housing, access to health care and a permanent residence title. In these struggles the appropriation of mobility remains contested and preliminary as long as migrants are haunted 
by the data traces they left behind when they initially applied for a Schengen visa and that are stored in VIS in order to facilitate their re-identification and deportation in case of detection by authorities. It is this self-perpetuating dynamic of migrants' struggles over the appropriation of mobility and other resources that makes the relation of conflict migrants' initiate within the border regime an irreconcilable conflict between migration and attempts of controlling it.

\section{Conclusion}

In this article I have described one set of practices by which migrants can appropriate mobility to Europe via Schengen visas in the context of biometric border controls. These practices involve the provision of falsified or manipulated supporting documents like job contracts upon which the decision to issue a biometric visa is based. After emphasising that these and other practices of appropriation are provoked by the Schengen visa regime itself, I have used this example to tease out six features that practices of appropriation share irrespective of their form. The aim was to develop a concept that addresses the two major points of critique that have been raised against the AoM approach.

The notion of appropriation dissolves the criticism that the AoM does not sufficiently consider the varying conditions under which people migrate insofar because it permits to locates moments of uncontrollability in the subjective practices of embodied migrants instead of attributing them to the anonymous, dynamic force of migration, as in the existing AoM literature. It thus invites scholars to focus on migrants' practices of appropriation in the analysis of contemporary border regimes in order to unearth - through a situated analysis of their embodied encounters with the actors, means and methods of control (Scheel 2013b) - how moments of uncontrollability and excess of migratory practices emerge in particular sites of border control. This conceptual framework permits to highlight that the tactics and practices a migrant deploys to appropriate mobility are shaped by her subject position in terms of class, 'race' and gender, the resources she can mobilise and the actors, means, methods and modes of mobility control she encounters.

Hence, the notion of appropriation is also well equipped to address the second critique that has been raised against the AoM. By highlighting the intricate entanglement of practices of appropriation and control and the resulting ambivalence of migrants' practices the notion of appropriation dissolves the critique that AoM does not sufficiently consider the restrictive effects of ever more laboured and sophisticated modes of border control. By introducing the notion of appropriation as a concept that highlights, more than existing concepts, the intricate 
intertwinement of migrants' practices with the means and methods of control, this article also makes a contribution to broader debates on migrant agency. Hence, the notion of appropriation hopefully provides critical border and migration studies scholars with a useful tool to intervene in migrants' mostly silent, but inherently political struggles over mobility and other resources by showing that it are the operational logics of today's ever more pervasive border regimes that provoke the very phenomena they are designed to combat and forestall.

\section{Acknowledgements}

I would like to thank all research participants for their time and for answering my questions, in particular the people who feature as Anas, M and P in this article. I would also like to thank Claudia Aradau, Jef Huysmans, Anne McNevin and the two anonymous reviewers who all provided very helpful comments on earlier drafts. This work was supported by funding from the European Research Council under the European Union's Seventh Framework Programme (FP/2007-2013) / ERC Grant Agreement no. 615588. Principal Investigator, Evelyn Ruppert, Goldsmiths, University of London.

\section{Disclosure Statement}

No potential conflict of interest was reported by the author.

\section{References}

Allou, Olivier. 2011. "Trafic de visas au sein des consulats et ambassades (Acte 1): Voici la stratégie des faussaires." In Parole d'Afrique (05.12.2011). Abidjan.

Alpes, Maybritt Jill 2011. Bushfalling: How Young Cameroonians Dare to Migrate, Faculty of Social and Behavioural Sciences. Amsterdam: Free University of Amsterdam.

Alpes, Maybritt Jill, and Alexis Spire. 2014. "Dealing with Law in Migration Control: The Powers of Street-level-Bureaucrats at French Consulates." Social \& Legal Studies 23 (2):261-74.

Bauder, Harold. 2013. "Why We Should Use the Term Illegalized Immigrant. RCIS Research Brief No. 2013/1 " In. Toronto: Ryerson Centre for Immigration \& Settlement.

Benz, Martina, and Helen Schwenken. 2005. "Jenseits von Autonomie und Kontrolle: Migration als eigensinnige Praxis." PROKLA - Zeitschrift für kritische Sozialwissenschaften 35 (140):363-77.

Bigo, Didier, and Elspeth Guild. 2005. "Policing at a Distance: Schengen Visa Policies." In Controlling Frontiers. Free Movement into and within Europe, edited by Didier Bigo and Elspeth Guild. Aldershot: Ashgate. 
Bouchard, Geneviève, and Barbara Wake Carroll. 2002. "Policy-making and Administrative Discretion: The Case of Immigration in Canada." Canadian Public Administration 45 (2):239-57.

Brabandt, Heike, and Steffen Mau. 2013. "Liberal Cosmopolitanism and Cross-Border Mobility: The Case of Visa Policies." Global Soeciety 27 (1):53-72.

Broeders, Dennis. 2007. "The New Digital Borders of Europe: EU Databases and the Surveillance of Irregular Migrants." International Sociology 22 (1):71-92.

Broeders, Dennis. 2011. "A European 'Border' Surveillance System under Construction." In Migration and the New Technological Borders of Europe, edited by Huub Dijstelbloem and Albert Meijer, 40-67. Basingstoke: Palgrave MacMillan.

CIMADE. 2010. "Visa refusé: Enquête sur les practiques des consulats de France en matière de delivrance des visas." In. Paris: CIMADE.

Council. 2001. "Council Regulation (EC) No 539/2001 of 15 March 2001 Listing the Third Countries whose Nationals must be in Possession of Visas when Crossing the External Borders and those whose Nationals are Exempt from that Requirement." In.

de Certeau, Michel 1984. The Practice of Everyday Life. Berkeley CA: University of California Press.

Düvell, Franck. 2011. "Paths into Irregularity: The Legal and Political Construction of Irregular Migration." Euopean Journal of Migration and Law 13 (3):275-95

EC. 2016. "Commision Staff Working Document SWD(2016) 328 final: 'Evaluation of the Implementation of Regulation (EC) No 767/2008 of the European Parliament and Council Concerning the Visa Information System (VIS) and the Exchange of Data between Member States on Short-stay Visas (VIS Regulation) REFIT Evaluation', Brussels, 14.10.2016".

EP and Council. 2008. "Regulation (EC) No 767/2008 of the European Parliament and Council of 9 July 2008 Concerning the Visa Information System (VIS) and the Exchange of Data between Member States on Short-stay Visas (VIS Regulation)." Official Journal of European Union (218):60-81.

EP and Council. 2009a. "Regulation (EC) No 81/2009 of the European Parliament and of the Council of 14 January 2009 Amending Regulation (EC) No 562/2006 as regards the Use of the Visa Information System (VIS) under the Schengen Borders Code." Official Journal of European Union:56-8.

EP and Council. 2009b. "Regulation (EC) No 810/2009 of the European Parliament and the Council of 13 July 2009 Establishing a Community Code on Visas (Visa Code) " In. Brussels: Official Journal of the European Union L 243.

Eule, Tobias, David Loher, and Anne Wyss. 2017. "Introduction." Journal of Ethnic and Migration Studies (Special Issue "Contested Control at the Margins of the State"). 
European Commission. 2010. "Commission Decision of 19.3.2010 on Establishing the Handbook for the Processing of Visa Applications and the Modification of Issued Visas. Brussels, 19.3.2010, C(2010) 1620 final." In.

Garcia, Sandrine. 1997. "La fraude forcée." Actes de la Recherche en Science Sociales (118):81-91.

Gofen, Anat. 2013. "Mind the Gap: Dimensions and Influence of Street-Level Divergence." Journal of Public Administration Research and Theory 24 (2):473-93.

Goffman, Erving. 1959. The Presentation of Self in Everyday Life. New York: Anchor Books.

Gold, Steve. 2012. "Border Control Biometrics and Surveillance " Biometric Technology Today 12 (7):9-11.

Gouteyron, Adrien. 2007. "Rapport d'information fait sur les services des visas, annexe au procès-verbale $\mathrm{N}^{\circ} 353$ de la séance du 27 juin 2007." In. Paris: Commission des Finances, du contrôle budgétaire et des comptes économiques de la Nation

Groebner, Valentin. 2004. Der Schein der Person. München: Beck.

Guild, Elspeth. 2001. "Moving the Border of Europe. Inaugural Lecture at the University of Nijmegen on 30 May 2001 ".

Hawkins, Keith. 1992. The Uses of Discretion. Oxford: Clarendon Press.

Hobolth, Mogens Hvam. 2012. Border Control Cooperation in the European Union: The Schengen Visa Policy in Practice Doctoral thesis defended at the London School of Economics and Political Science.

Infantino, Federica. 2016. "State-bound Visa Policies and Europeanized Practices. Comparing EU Visa Policy Implementation in Morocco." Journal for Borderland Studies 31 (2):171-86.

Infantino, Federica, and Andrea Rea. 2012. "La mobilisation d'un savoir pratique local: attribution des visas Schengen au Consulat général de Belgique à Casablanca." Sociologies Pratiques (24):67-78.

Jansen, Yolande, Robin Celikates, and Joost De Bloois. 2015. "Introduction." In The Irregularization of Migration in Contemporary Europe. Detention, Deportation, Drowning, edited by Yolande Jansen, Robin Celikates and Joost De Bloois, 9-24. New York: Rowman \& Littlefield.

Karakayali, Serhat, and Vassilis Tsianos. 2005. "Mapping the Order of New Migration. Undokumentierte Arbeit und die Autonomie der Migration." Peripherie 25 (97/98):35-64.

Lipsky, Michael. 1980. Street-Level Bureaucracy: Dilemmas of the Individual in Public Services. New York: Russell Sage Foundation.

Mau, Steffen. 2010. "Mobility Citizenship, Inequality, and the Liberal State: The Case of Visa Policies." International Political Sociology 4 (4):339-61. 
Maynard-Moony, Steven, and Michael Musheno. 2003. Cops, Teachers, Counselors. Stories from the Frontline of Public Service. Ann Arbor: University of Michigan Press.

Mezzadra, Sandro. 2011. "The Gaze of Autonomy: Capitalism, Migration and Social Struggles." In The Contested Politics of Mobility Borderzones and Irregularity edited by Vicky Squire, 121-42. London: Routledge.

Moulier Boutang, Yann. 1993. "Interview." In Materialien für einen neuen Antiimperialismus Nr. 5, edited by N.N., 29-56. Berlin Göttingen Schwarze Risse/ Rote Straße.

Moulier Boutang, Yann. 2007. "Europa, Autonomie der Migration, Biopolitik." In Empire und die biopolitische Wende. Die Internationale Diskussion im Anschluss an Negri und Hardt, edited by Marianne Pieper, Thomas Atzert, Serhat Karakayali and Vassilis Tsianos, 169-78. Frankfurt am Main: Campus.

Muller, Benjamin. 2010. Security, Risk and the Biometric State. Oxon/ New York: Routledge.

Neumayer, Eric. 2006. "Unequal Access to Foreign Spaces: How States Use Visa Restrictions to Regulate Mobility in a Globalized World." Transactions of the Institute of British Geographers 31 (1):72-84.

Omwenyeke, Sunny. 2004. "Autonomy of Migration: Where We Stand in the Debate."

Papadopoulos, Dimitris, Niamh Stephenson, and Vassilis Tsianos. 2008. Escaperoutes. Control and Subversion in the Twenty-first Century. London: Pluto Press.

Parusel, Bernd, and Jan Schneider. 2012. "Visa Policy as Migration Channel: The Impact of Visa Policy on Migration Control. Study by the German Contact Point of the European Migration Network (EMN)." In. Nürnberg: Federal Office for Migration and Refugees.

Scheel, Stephan. 2013a. "Autonomy of Migration Despite Its Securitisation? Facing the Terms and Conditions of Biometric Rebordering." Millennium - Journal of International Studies 41 (3):575-600.

Scheel, Stephan. 2013b. "Studying Embodied Encounters: Autonomy of Migration Beyond its Romanticization." Postcolonial Studies 16 (3):279-88.

Scheel, Stephan. forthcoming. Autonomy of Migration? Appropriating Mobility Within Biometric Border Regimes. London and New York: Routledge.

Scott, James C. 1985. Weapons of the Weak: Everyday Forms of Peasant Resistance Betany: Brevis Press.

Sharma, Nandita. 2009. "Escape Artists: Migrants and the Politcs of Naming." Subjectivtity 29 (1):467-76.

Sontowski, Simon. 2017. "Speed, Timing and Duration: Contested Temporalities, TechnoPolitical Controversies and the Emergence of the EU's Smart Border." Journal of Ethnic and Migration Studies (Special Issue "Contested Control at the Margins of the State"). 
Spire, Alexis. 2009. Accueillir ou reconduire: Enquête sur les guichets de l'immigration. Paris: Raisons d'Agir Éditions.

Van Houtum, Henk. 2010. "Human Blacklisting: the Global Apartheid of the EU's External Border Regime." Environment and Planning D: Society and Space 28 (6):957-76.

Zampagni, Francesca. 2013. Who Moves? Schengen Visa Policies and Implementation in Consulates: A Fieldwork Study from the Embassy of Italy in Senegal. Doctoral thesis defended at the Department of Political Science of the University of Pisa.

Zampagni, Francesca. 2016. "Unpacking the Schengen Visa Regime. A Study on Bureaucrats and Discretion in an Italian Consulate." Journal for Borderland Studies 31 (2):25166.

\section{Notes}

${ }^{1}$ In the following I use the criminalising terms 'illegal' migrant or 'illegal' migration only if the EU's
official terminology is unavoidable. In order to highlight the active role that statist institutions play in the processes that make people 'illegal' I speak of 'illegalised migrants' instead (Bauder 2013).

${ }^{2}$ These were Algeria, Egypt, Libya, Mauritania, Morocco and Tunisia. Since then the VIS has been gradually implemented in consulates across the world.

${ }^{3}$ In this article I refer to the Schengen area when using the term 'Europe' as a Schengen visa permits its holder to travel freely across all 26 Schengen member states for the duration of the visa.

${ }^{4}$ The following account is a condensed version of arguments that are developed in more detail in a forthcoming book in which a whole chapter is devoted to the reading of the Schengen visa regime as an unpredictable regime of institutionalised distrust (Scheel forthcoming).

${ }^{5}$ Following a regulation by the European Council, the decision to impose or lift a visa requirement is based on the assessment of the population according to three criteria, 'relating inter alia to illegal immigration, public policy and security' (Council 2001, 3 ; for a critique of these murky criteria see: Guild 2001).

${ }^{6}$ The pejorative term of 'visa shopping' refers, first, to practice of visa applicants to lodge further applications at consulates of one or several other Schengen member states, after an initial application has already been turned down, and second, to the practice of lodging an application at the consulate of another member state than the one that is responsible for processing the application. Following article 5 of the Community Code on Visa (CCV), applicants are required to apply for a Schengen visa at the consulate of the member state that constitutes 'the main destination of the visit(s) in terms of length or purpose of stay' (EP and Council 2009b, 6).

${ }^{7}$ Following articles 8(2) and 15 of the VIS-regulation (EP and Council 2008) and article 21(2) of the CCV (EP and Council 2009b), consular staff have to conduct a search in the VIS with the applicant's 
fingerprints during the visa application procedure. This is why also the biometric and biographical data of all persons whose visa applications have been rejected are stored for five years in the VIS.

${ }^{8}$ Keeping 'blacklists' of applicants who have breached the Schengen visa regime's rules is not foreseen by the CCV. Following M, each visa section keeps its own 'blacklist'. While visa sections inform each other about 'abusive' applicants, it is at the discretion of each consulate's staff to decide whether to add a particular applicant to their 'blacklist'. M could not tell me how many names were on consular Z's 'blacklist' as he could neither evaluate the list statistically nor delete any names from the list which is searched automatically by the software when he processes a visa application.

${ }^{9}$ Migration from Turkish and African coasts to European islands constitutes a noteworthy exception to this rule, as it involves being 'rescued' by the coastguard - i.e. recoding these actors of mobility control into a means enabling its appropriation - and spending some time in detention camps on the island before being transferred to the European mainland. But once there, the success of the appropriation of mobility hinges again on remaining undetected and avoiding attracting any attention. For migrants usually disappear to lead a life under conditions of illegality and collectively organised invisibility (Papadopoulos, Stephenson, and Tsianos 2008).

${ }^{10}$ In fact, this practice seems to exist in many countries. In her research on consular practices in Senegal, Francesca Zampagni mentions the practice of issuing employment contracts to friends and relatives $(2013,89)$. 'Real fakes' also feature in a newspaper article on the appropriation of Schengen visas in Ivory Coast (Allou 2011). The practice of drawing up 'employment contracts [...] for friends or relatives to facilitate the issuing of a visa, though the persons concerned are not actually employed' is also mentioned in a handbook on the issuance of Schengen visa published by the EC $(2010,57)$. 